\title{
PENTINGNYA KEPERCAYAAN DIRI DAN MOTIVASI SOSIAL DALAM KEAKTIFAN MENGIKUTI PROSES KEGIATAN BELAJAR
}

\author{
Fani Juliyanto Perdana \\ Sekolah Tinggi Ilmu Kesehatan Cirebon \\ fanijuliyanto@gmail.com
}

\begin{abstract}
ABSTRAK
Setiap kepribadian manusia, percaya diri merupakan indikator yang penting untuk menghasilkan keberhasilan dalam kaitannya dengan aktivitas yang ia lakukan. Akan tetapi ada hal yang tidak bisa dipungkiri bahwa tingkat kepercayaan diri yang dimiliki oleh masing-masing individu berbeda-beda, dan al tersebut dipengaruhi oleh faktor lain disamping proses pendewasaan dirinya sendiri. Percaaya diri seorang mahasiswa dalam keaktifannya ketika mengikuti KBM tidak hanya dipengaruhi oleh motivasi sosial tetapi juga dipengaruhi oleh kemampuan dalam pengetahuan yang ia miliki. Dalam pembahasan pada penelitian ini yaitu untuk membantu bagaimana cara menumbuhkan rasa percaya diri bagi mahasiswa dalam keaktifannya ketika mengikuti proses KBM, bagaimana motivasi sosial mahasiswa STIKes Cirebon. Bagaimana pengaruh antara kepercayaan diri terhadap motivasi dalam keaktifan mengikuti proses KBM di STIKes Cirebon. Populasi dalam penelitian ini adalah mengambil sampel pada mahasiswa tingkat I semester I Program Studi Kesehatan Masyarakat STIKes Cirebon Tahun Akademik 2018/2019 yang berjumlah 23 mahasiswa, Penelitian ini dilakukan dengan menggunakan metode deskriptif kualitatif. Karena metode ini dianggap mampu untuk mengungkap, menggali dan menganalisis fenomena empirik yang terjadi pada masa sekarang dengan cara memaparkan atau menggambarkan sesuai dengan fakta yang terjadi dari hasil penelitian tersebut.
\end{abstract}

Kata Kunci : Kepercayaan Diri, Motivasi, Keaktifan, Mahasiswa

\begin{abstract}
Every human personality, confidence is an important indicator to produce success in relation to the activities that he does. However, there are things that cannot be denied that the level of confidence possessed by each individual is different, and al is influenced by other factors besides the process of maturity itself. A student's confidence in his activities when participating in teaching and learning activities is not only influenced by social motivation but also influenced by the ability in the knowledge he has. In the discussion in this research that is to help how to grow self-confidence for students in their activities when following the process of teaching and learning activities, how the social motivation of students of STIKes Cirebon. How is the influence between self-confidence on motivation in activeness to follow the process of teaching and learning activities at STIKes Cirebon. The population in this study was to take samples at the first
\end{abstract}


semester level I students of the STIKes Cirebon Public Health Study Program in 2018/2019 with a total of 23 students, this study was conducted using descriptive qualitative methods. Because this method is considered able to uncover, explore and analyze empirical phenomena that occur at the present time by describing or describing in accordance with the facts that occur from the results of the study.

\section{Keywords : Confidence, Motivation, Activeeness, Students}

\section{A. PENDAHULUAN}

Pada hakikatnya setiap manusia diciptakan dengan memiliki rasa percaya diri, namun rasa percaya diri itu berbeda antara orang yang satu dengan yang lain. Ada yang memiliki rasa percaya diri kurang dan ada yang memiliki lebih, sehingga keduanya menampakkan perbedaan tingkah laku. Tidak semua manusia diciptakan dengan memiliki rasa kepercayaan diri yang tinggi, sebagian memiliki rasa kurang percaya diri.

Hal demikian akan menunjukkan perilaku yang berbeda dengan orang pada umumnya seperti tidak bisa berbuat banyak, selalu ragu dalam menjalankan tugas, tidak berani berbicara banyak jika tidak mendapat dukungan dan lain sebagainya kekurangan-kekurangan yang dirasakan. Seseorang yang mempunyai rasa percaya diri lebih, ia merasa yakin dengan kemampuannya sendiri sehingga dapat dilihat tingginya keberanian, hubungan sosial, tanggung jawab serta harga dirinya.

Rasa percaya diri memang sangat diperlukan dalam menjalani hidup, termasuk dalam perjuangan mendapatkan pasangan. Banyak orang mengira kepercayaan diri adalah hal yang tak bisa dipelajari. Mereka menganggap kepercayaan diri berasal dari takdir, sehingga membuat mereka malas untuk berusaha mengembangkan dan melatih rasa percaya dirinya. Nyatanya, rasa percaya diri dapat dipupuk dan dipelajari.

Semua orang bisa hidup dengan kepercayan diri penuh, asalkan terus melatih dan mengembangkannya. Kepercayaan diri adalah hal yang muncul seiring berjalannya waktu. Memang, ada beberapa orang yang nampak lahir dengan rasa percaya diri penuh. Sebenarnya, rasa percaya diri itu muncul dari kombinasi pola asuh dan peristiwa yang terjadi di masa perkembangan. Memang butuh waktu yang lama untuk mengembangkannya. Tapi, dengan terus berusaha 
mengembangkan rasa percaya diri, kita juga turut berkembang menjadi manusia yang lebih baik (Anggraini, $2018: 1$ ).

Menumbuhkan rasa percaya diri adalah hal penting. Cukup membangun rasa percaya diri dalam satu bidang kehidupan, maka hal itu akan menyebar ke semua aspek dalam hidup kita. Terkadang rasa percaya diri bisa muncul secara berlebihan yang mengarah pada kesombongan. Mereka yang merasa rendah diri biasanya berpura-pura memiliki rasa percaya diri yang kuat. Semakin merasa minder, semakin ia tampil dengan rasa percaya diri yang semu. Kurangnya kecerdasan sosial itu membuatnya menjadi orang yang arogan.

Rasa percaya diri itu bisa dibangun dan dikembangkan secara positif dan objektif sejak anak usia balita. Pengaruh utama dan pertama untuk memasuki kesan-kesan yang menarik bagi anak adalah lingkungan, karena lingkungan merupakan faktor yang pertama anak mengalami perubahan. Anak akan meniru tingkah laku maupun ucapan yang ia lihat, misalnya ketika anak bermain atau bersama teman-temannya, nampak sikapnya yang polos, mau menang sendiri, merebut dan menggunakan mainan yang ia lihat dengan tanpa merasa takut dan malu.

Mengingat betapa pentingnya rasa percaya diri ini, maka setiap tempat dan suasana perlu dibangun secara optimal dan positif. Bagi orang tua dan pendidik diharapkan wajib membantu perkembangan rasa percaya diri pada anak dan samasama saling menyadari bahwa dengan dimilikinya rasa percaya diri yang positif pada diri anak akan membawa keuntungan di berbagai pihak.

Salah satu ciri khas yang dimiliki oleh kepribadian introvert adalah kemampuan untuk berpikir matang sebelum bicara. Mengungkapkan isi pikiran dalam bentuk tulisan adalah keahliannya. Salah satu unsur penting presentasi adalah materi yang runut dan komprehensif. Kita dapat mencapainya dengan membuat slide presentasi yang menarik. Tuangkan apa yang ingin disampaikan dalam bentuk slide-slide yang atraktif. Selain akan membuat audiens tertarik, slide-slide presentasi itu juga akan menjadi panduan untuk menyampaikan materi presentasi. 
Apa yang membuat presentasi terkesan mengerikan adalah karena kita tidak tahu apa yang akan terjadi di sana. Persiapan yang sudah kita lakukan dengan matang bisa hancur berantakan begitu kita tampil dan melihat apa yang di sana tidak sesuai dengan yang kita persiapkan. Berlatih presentasi di depan cermin adalah yang paling umum. Kita bisa mengatur nada suara, arah pandangan, dan mengetes sejauh mana kita akan menyampaikan materi. Jangan ragu juga untuk mencoba presentasi di hadapan teman. Agar membuat kesan bahwa kita berada dalam presentasi sesungguhnya, kita menginstruksikan mereka untuk mengajukan pertanyaan. Dengan begitu kita terkesan sudah mengantisipasi apa yang mungkin terjadi ketika presentasi yang sesungguhnya.

Pada masa sekarang ini banyak sekali problematika yang dialami oleh peserta didik mengenai belajar, salah satunya adalah problematika tentang kurangnya semangat peserta didik untuk belajar. Banyak faktor yang mempengaruhi peserta didik menjadi malas belajar. Faktor faktor tersebut antara lain : kurangnya motivasi sosial.

Motivasi sosial merupakan dorongan mental yang menggerakkan dan mengarahkan perilaku manusia ke dalam bentuk aktivitas nyata untuk memperoleh suatu perubahan tingkah laku sebagai hasil dari pengalaman individu dalam interaksi dengan lingkungannya yang menyangkut kognitif, afektif, dan psikomotorik. Kurangnya motivasi pada peserta didik sangatlah berpengaruh, karena motivasi memegang peran penting dalam proses belajar. Apabila orang tua dan pendidik dapat memberikan motivasi yang baik pada peserta didik, maka dalam diri peserta didik akan timbul dorongan dan hasrat untuk lebih meningkatkan belajarnya. Dengan memberikan motivasi yang baik maka peserta didik akan menyadari manfaat belajar.

\section{B. KAJIAN TEORI}

\section{Pengertian Percaya Diri}

Percaya diri merupakan salah satu aspek kepribadian yang sangat penting dalam kehidupan manusia. Orang yang percaya diri yakin atas kemampuan mereka sendiri serta memiliki pengharapan yang realistis, bahkan ketika 
harapan mereka tidak terwujud, mereka tetap berpikiran positif dan dapat menerimanya. Menurut Thantaway dalam Kamus istilah Bimbingan dan Konseling (2005:87), percaya diri adalah kondisi mental atau psikologis diri seseorang yang memberi keyakinan kuat pada dirinya untuk berbuat atau melakukan sesuatu tindakan. Orang yang tidak percaya diri memiliki konsep diri negatif, kurang percaya pada kemampuannya, karena itu sering menutup diri.

Kalau melihat ke literatur lainnya, ada beberapa istilah yang terkait dengan persoalan pede/percaya diri yaitu ada empat macam, yaitu :

a. Self-concept : bagaiman menyimpulkan diri kita secara keseluruhan, bagaimana melihat potret diri kita secara keseluruhan, bagaimana mengkonsepsikan diri kita secara keseluruhan.

b. Self-esteem : sejauh mana kita punya perasaan positif terhadap diri kita, sejauhmana kita punya sesuatu yang dirasakan bernilai atau berharga dari diri kita, sejauh mana kita meyakini adanya sesuatu yang bernilai, bermartabat atau berharga di dalam diri kita.

c. Self efficacy : sejauh mana kita punya keyakinan atas kapasitas yang kita miliki untuk bisa menjalankan tugas atau menangani persoalan dengan hasil yang bagus (to succeed). Ini yang disebut dengan general self-efficacy. atau juga, sejauhmana Kita meyakini kapasitas di bidang kita dalam menangani urusan tertentu. Ini yang disebut dengan specific self-efficacy.

d. Self-confidence : sejauhmana kita punya keyakinan terhadap penilaian kita atas kemampuan kita dan sejauh mana kita bisa merasakan adanya "kepantasan" untuk berhasil. Self confidence itu adalah kombinasi dari self esteem dan self-efficacy.

Ketika ini dikaitkan dengan praktek hidup sehari-hari, orang yang memiliki kepercayaan diri rendah atau telah kehilangan kepercayaan, cenderung merasa atau bersikap sebagai berikut :

a. Tidak memiliki sesuatu keinginan, tujuan, atau target yang diperjuangkan secara sungguh sungguh.

b. Tidak memiliki keputusan melangkah yang decissive (ngambang). 
c. Mudah frustasi atau give-up ketika menghadapi masalah atau kesulitan.

d. Kurang termotivasi untuk maju, malas-malasan atau setengah-setengah.

e. Sering gagal dalam menyempurnakan tugas-tugas atau tanggung jawab.

f. Canggung dalam menghadapi orang.

g. Tidak bisa mendemonstrasikan kemampuan berbicara dan kemampuan mendengarkan yang meyakinkan.

h. Sering memiliki harapan yang tidak realistis.

i. Terlalu perfeksionis.

j. Terlalu sensitif (perasa).

Sebaliknya, orang yang mempunyai kepercayaan diri bagus, mereka memiliki perasaan positif terhadap dirinya, punya keyakinan yang kuat atas dirinya dan punya pengetahuan akurat terhadap kemampuan yang dimiliki. Orang yang punya kepercayaan diri bagus bukanlah orang yang hanya merasa mampu (tetapi sebetulnya tidak mampu) melainkan adalah orang yang mengetahui bahwa dirinya mampu berdasarkan pengalaman dan perhitungannya.

2. Motivasi sosial

Terkait dengan motivasi, banyak pakar yang telah mengemukakan teorinya berdasarkan sudut pandangnya masing-masing. Teori motivasi tersebut diantaranya adalah teori yang dikembangkan oleh Maslow dikenal dengan hierarki kebutuhan Maslow. Maslow (dalam Dimyati, 2009 : 81) berpendapat bahwa manusia mempunyai lima tingkat kebutuhan, yaitu :

a. Kebutuhan fisiologis, seperti rasa lapar, haus, istirahat dan biologis.

b. Kebutuhan akan perasaan aman, dalam hal ini tidak dalam arti fisik semata, akan tetapi juga mental, psikologikal dan intelektual.

c. Kebutuhan sosial.

d. Kebutuhan akan penghargaan diri, yang pada umumnya tercermin dalam berbagai simbol-simbol status, dan

e. Kebutuhan akan aktualisasi diri, dalam arti tersedianya kesempatan bagi seseorang untuk mengembangkan potensi yang terdapat dalam dirinya sehingga berubah menjadi kemampuan nyata. 
Hierarki di atas di dasarkan pada anggapan bahwa pada waktu orang telah memuaskan satu tingkat kebutuhan tertentu, mereka ingin bergeser ke tingkat kebutuhan yang lebih tinggi. Menurut Mc. Donald (dalam Djamarah, 2008 : 148) yang mengatakan bahwa motivasi adalah suatu perubahan energi di dalam pribadi seseorang yang ditandai dengan timbulnya afektif atau perasaan dan reaksi untuk mencapai tujuan. Perubahan energi dalam diri seseorang itu dapat berbentuk suatu aktivitas nyata berupa kegiatan fisik. Oleh karena seseorang mempunyai tujuan dalam aktivitasnya, maka seseorang mempunyai motivasi yang kuat untuk mencapainya dengan segala upaya yang dapat dia lakukan.

Woodworth dan Marques (Sunarto, 2006 : 18), mendefinisikan motivasi sebagai satu set motif atau kesiapan yang menjadikan individu cenderung melakukan kegiatan-kegiatan tertentu dan untuk mencapai tujuan-tujuan tertentu. Pendapat tersebut senada dengan yang disampaikan oleh Chung dan Meggison, yang mendefinisikan motivasi sebagai prilaku yang ditujukan kepada sasaran, motivasi berkaitan dengan tingkat usaha yang dilakukan oleh seseorang dalam mengejar suatu tujuan. Motivasi juga berkaitan erat dengan kepuasan dalam pekerjaan.

Motivasi dan belajar merupakan dua hal yang saling mempengaruhi. mahasiswa akan giat belajar jika ia mempunyai motivasi untuk belajar. Thorndike (Hamzah B. Uno, 2011 : 11) mendefinisikan belajar sebagai proses interaksi antara stimulus (yang mungkin berupa pikiran, perasaan, atau gerakan) dan respon. Pengertian ini senada dengan pendapat Good dan Brophy (Hamzah B. Uno, 2011 : 15), yang menyatakan bahwa belajar merupakan suatu proses atau interaksi yang dilakukan seseorang dalam memperoleh sesuatu yang baru dalam bentuk perubahan perilaku sebagai hasil dari pengalaman belajar. Perubahan tingkah laku tersebut tampak dalam penguasaan mahasiswa pada pola-pola tanggapan (respon) baru terhadap lingkungannya yang berupa keterampilan (skill), pengetahuan (knowledge), sikap atau pendirian (attitude), kemampuan (ability), pemahaman (understanding), emosi (emotion), apresiasi, jasmani, budi pekerti, serta hubungan sosial. 


\section{Keaktifan}

Menurut kamus besar bahasa Indonesia (Badan Pengembangan Bahasa dan Perbukuan, 2016 : 1) keaktifan dalam belajar berarti giat, baik dalam bekerja atau berusaha. Keaktifan diartikan sebagai hal atau keadaan dimana mahasiswa dapat aktif. Dengan demikian keaktifan dapat dari dalam proses pembelajaran. Apabila siswa aktif maka mahasiswa dapt mengembangkan sendiri potensi yang ada pada diri mereka, oleh sebab itu perlu diciptakan pembelajaran aktif untuk mendukung potensi mahasiswa. Pembelajaran aktif (active learning) dimaksudkan untuk mengoptimalkan penggunaan semua potensi yang dimiliki oleh peserta didik, sehingga semua peserta didik dapat mencapai hasil belajar yang memuaskan sesuai dengan karakteristi pribadi yang mereka miliki (Eveline Siregar dan Hartini Nara, 2010 : 106).

Proses pembelajaran pada hakekatnya untuk mengembangkan aktivitas dan kreatifitas peserta didik melalui berbagai interaksi dan pengalaman belajar. Keaktifan belajar mahasiswa merupakan unsur dasar yang penting bagi keberhasilan proses pembelajaran. Keaktifan adalah kegiatan yang bersifat fisik maupun mental, yaitu berbuat dan berfikir sebagai suatu rangkaian yang tidak dapat dipisahkan (Sardiman, 2010 : 98).

Menurut Basyiruddin Usman, cara yang dapat dilakukan oleh seorang tenaga pendidik untuk memperbaiaki keterlibatan peserta didik antara lain dengan meningkatkan persepsi peserta didik secara aktif dalam kegiatan belajar mengajar menbuat respon yang aktif dari peserta didik, melakukan masa transisi antara kegiatan dalam mengajar dengan secara cepat dan luwes, memberikan pelajaran yang jelas dan tepat sesuai dengan tujuan mengajar yang akan dicapai, mengusahakan agar pengajaran dapat lebih memacu minat mahasiswa (Basyiruddin Usman, 2002 : 26). Jadi, keaktifan belajar adalah kemampuan mahasiswa secara mandiri dan aktif dalam belajar yang akan diciptakan oleh dosen dalam proses pembelajaran.

Belajar yang berhasil harus melalui berbagai macam aktifitas, baik aktifitas fisik maupun psikis. Aktifitas fisik adalah mahasiswa giat aktif dengan anggota badan, membuat sesuatu, bermain maupun bekerja, ia tidak hanya 
duduk dan mendengarkan, melihat atau hanya pasif. Mahasiswa yang memiliki aktifitas psikis atau kejiwaan yaitu jika daya jiwanya bekerja sebanyakbanyaknya atau banyak berfungsi dalam rangka pembelajaran.

\section{METODE PENELITIAN}

Metode penelitian yang digunakan dalam penelitian ini adalah deskriptif kualitatif. Penelitian deskriptif kualitatif merupakan salah satu dari jenis penelitian yang termasuk dalam jenis penelitian kualitatif. Adapun tujuan dari penelitian ini adalah untuk mengungkapkan kejadian atau fakta, keadaan, fenomena, variabel dan keadaan yang terjadi saat penelitian berlangsung dengan menyuguhkan apa yang sebenarnya terjadi. Penelitian ini menafsirkan dan menguraikan data yang bersangkutan dengan situasi yang sedang terjadi, sikap serta pandangan yang terjadi di dalam suatu masyarakat, pertentangan antara dua keadaan atau lebih, hubungan antar variable yang timbul, perbedaan antar fakta yang ada serta pengaruhnya terhadap suatu kondisi, dan sebagainya.

Analisis data dilakukan secara kualitatif dengan langkah :

a. Pengumpulan data.

b. Reduksi data.

c. Penyajian dan klasifikasi data, dan

d. Penarikan kesimpulan dan verifikasi (Nugroho, 2017 : 129).

Dalam penelitian ini teknik yang digunakan dalam pengumpulan data dengan menggunakan :

a. Observasi, adalah salah satu teknik pengumpulan data yang dilakukan dengan cara melakukan pengamatan terhadap objek penelitian. Observasi dapat dilakukan terhadap fenomena sosial atau gejala-gejala peristiwa alam dalam kegiatan penelitian lapangan (Muhammad Ali, 2007 : 62).

b. Wawancara, adalah percakapan dengan maksud tertentu. Percakapan itu dilkaukan oleh dua pihak, yaitu pewawancara (interviewer) yang mengajukan pertanyaan dan terwawawancara (interviewer) yang member jawaban (Noeng Muhadjir, 2007 : 186). 
c. Dokumentasi, adalah data dalam penelitian yang diperoleh dari sumbersumber atau informasi melalui observasi dan wawancara yang berupa buku harian, surat-surat, foto, notulensi rapat, laporan dan lain-lain (Nasution, $2004: 85$ ).

d. Focus Group Discussion (FGD), sebagai teknik pengumpulan data untuk menemukan makna menurut pemahaman sebuah kelompok berdasarkan hasil diskusi yang terpusat pada permasalahan tertentu. (Burhan Bungin, $2008: 16)$.

Dengan demikian, penelitian hal ini dimaksudkan sebagai upaya untuk mengetahui tentang dampak dari kepercayaan diri yang dimiliki mahasiswa dalam keaktifannya dalam mengikuti proses KBM berdasarkan motivasi sosialnya. Dalam melakukan penelitian ini, terdapat 4 buah narasi untuk empat kelompok. Total responden adalah 20 mahasiswa dan dibagi menjadi 4 kelompok, dan masing-masing kelompok terdiri dari 5 mahasiswa.

Tema diskusi kelompok dibuka dengan instruksi bahwa masing-masing kelompok diminta untuk berperan sebagai sebuah team yang dalam tersebut digambarkan bahwa, Hari ini diadakan sebuah diskusi kelompok, masingmasing kelompok akan diberi tema yang berbeda, lalu mempresentasikan hasil diskusi tersebut dengan matang didepan kelompok lainnya. Tiap kelompok diperbolehkan bertanya kepada kelompok yang sedang mempresentasikan hasil diskusinya. Kelompok yang paling baik dalam mempresentasikan, menjawab pertanyaan, serta keaktifan seluruh anggota kelompok akan dinilai.

Penilaian aspek Kepercayaan diri diukur dengan kesadaran partisipan dalam mendiskusikan tema yang diberikan, mencari materi sebaik mungkin, serta mempresentasikan didepan kelompok lain. Dalam kegiatan ini diikuti oleh seluruh mahasiswa program Studi Kesehatan Masyarakat tingkat I, semester I yang berjumlah sebanyak 20 mahasiswa yang terbagi dalam 4 kelompok. Aspek Motivasi sosial diukur dengan bagaimana mereka merespon pertanyaan dari kelompok lain, ketika mereka bertanya atau berkomentar terhadap hasil diskusi dari tiap-tiap kelompok. Skala Keaktifan dalam mengikuti proses KBM dalam penelitian ini dikumpulkan dengan 
menggunakan skala intensi perilaku prososial. menggunakan konsep diskusi kelompok yang mencerminkan Keaktifan masing-masing mahasiswa.

\section{HASIL DAN PEMBAHASAN}

1. Membangun rasa kepercayaan diri

Rasa percaya diri, yang merupakan kombinasi antara keyakinan pada kemampuan dan penghargaan kepada diri sendiri, adalah aspek yang sangat penting dalam kehidupan seorang manusia (Mind Tools, 2019 : 1). Keyakinan pada kemampuan adalah perasaan atau percaya bahwa kita dapat melaksanakan berbagai tugas atau mencapai tujuan dalam hidup. Penghargaan kepada diri sendiri juga sama, tetapi lebih kepada percaya bahwa pada umumnya kita kompeten dalam hal apa pun yang kita lakukan dan kita layak berbahagia dalam hidup.

Orang yang percaya diri biasanya menyukai dirinya sendiri, mau mengambil risiko untuk mencapai tujuan pribadi dan profesional, dan selalu berpikir positif akan masa depan. Akan tetapi, orang yang yang tidak memiliki kepercayaan diri merasa kurang mampu mencapai tujuannya, dan cenderung memiliki pandangan negatif kepada dirinya sendiri dan apa yang ingin dia capai dalam hidup.

a. Menanamkan sikap yang baik

Sikap kita adalah sebagian besar dari diri kita sesuai persepsi kita tentang realitas. Intinya adalah bagaimana kita memilih untuk menghadapi setiap situasi atau cara dan konsekuensi dari setiap pilihan yang kita buat. Apakah kita sudah berperilaku dengan cara yang positif atau negatif, kita sendiri yang dapat menentukan apa yang akan kita lakukan.

Kesempurnaan dalam sikap dan perilaku memang tidak mudah, akan tetapi kita dapat memaksimalkan sikap positif tersebut sesuai dengan kemampuan kita. Berikut adalah beberapa sikap yang mengandung penanaman sikap yang baik dalam diri kita yang dapat membangun rasa kepercayaan diri, antara lain : 
1) Mengenali pikiran negatif (Burton, 2012 : 1). Pikiran negatif biasanya berwujud dalam kalimat "aku tidak bisa", "aku pasti gagal", "tidak ada yang mau mendengarkan apa yang ingin kukatakan". Suara-suara ini pesimis, tidak membantu, dan akan menghalangi kita untuk memiliki harga diri yang tinggi dan rasa percaya diri yang besar.

2) Gantilah pikiran negatif dengan pikiran positif. Jika kita sadar bahwa kita berpikir negatif, alihkan ke pikiran yang positif. seperti "akan kucoba", "aku bisa berhasil jika mau berusaha", atau "orang-orang pasti mau mendengarkan aku".

3) Jangan biarkan pikiran negatif muncul lebih sering daripada pikiran positif. Pikiran positif harus mengisi lebih banyak ruang otak, lalu dibandingkan pikiran negatif. Semakin sering kita melawan pikiran negatif dengan pikiran positif, kita akan semakin terbiasa melakukannya.

4) Miliki jaringan pendukung yang positif dan dekatkan diri kepada orangorang tercinta agar kita tetap gembira, seperti keluarga atau teman-teman. Selain itu, jauhilah orang-orang atau hal-hal yang membuat perasaan kita tidak baik.

5) Hilangkan apa pun yang dapat memunculkan pikiran negatif. Jangan biarkan diri kita berada dalam situasi yang membuat kita merasa negatif kepada diri sendiri.

6) Kenali bakat kita. Setiap orang mempunyai keahlian, jadi carilah apa yang mampu kita lakukan dengan baik, lalu berfokuslah pada bakat kita. Temukan apa yang kita sukai lalu kembangkan bakat yang sesuai dengan minat kita tersebut.

7) Banggalah kepada diri sendiri. kita tidak cuma harus bangga dengan bakat atau keahlian, tetapi juga harus memperhatikan semua hal yang membuat kepribadian kita istimewa.

8) Terimalah pujian dengan anggun. Orang-orang yang rendah diri biasanya sulit menerima pujian. Mereka menganggap bahwa pujian itu keliru atau bohong, kita harus mengubah cara kita menanggapi pujian. 
9) Tatap diri kita di cermin dan tersenyumlah. ekspresi wajah sebenarnya dapat memengaruhi otak untuk membentuk atau memperkuat emosi tertentu. Jadi, dengan bercermin dan tersenyum setiap hari, lama-kelamaan kita bisa merasa lebih bahagia dengan diri sendiri dan lebih percaya diri.

b. Menangani emosi

Tidak jarang emosi-emosi negatif seperti kecewa dan marah menguasai, sehingga kita menjadi tidak dapat berkonsentrasi. Bahkan, kita melakukan hal-hal yang merugikan diri sendiri dan orang lain. Ini mengapa penting untuk tahu cara mengendalikan emosi. Penelitian menemukan bahwa respons emosional manusia berasal dari cara mereka menilai pengalaman tertentu. Emosi adalah ekspresi normal atas berbagai hal yang terjadi dalam keseharian, seperti tertawa karena kejadian lucu hingga merasa kesal setelah terjebak macet. Mengekspresikan emosi secara tepat dan mengetahui cara mengendalikan emosi akan membuat diri kita merasa lebih baik.

Tidak jarang emosi-emosi negatif membuat kita menjadi berperilaku negatif juga. Marah, sedih, kecewa memang tidak dapat dihindari, tetapi dapat dikelola. Ekspresi emosi negatif bahkan dapat membahayakan hubungan pertemanan, pekerjaan, dan bahkan kesehatan kita sendiri. Hal inilah yang membuat kita perlu belajar cara mengendalikan emosi. Dalam menangani emosi, di bawah ini ada beberapa hal yang dapat membantu kita, yakni :

1) Hadapi rasa takut dengan nyaman.

2) Bersabarlah dengan diri sendiri.

3) Usahakan menemukan keseimbangan.

4) Berhentilah membandingkan diri sendiri dengan orang lain.

5) Akui apa yang membuat kita minder.

6) Bangkitlah dari kesalahan.

7) Hindari perfeksionisme.

8) Belajarlah untuk bersyukur.

c. Belajar memperhatikan diri sendiri 
Diri kita adalah pusat kehidupan kita. Kesadaran untuk memperhatikan diri sendiri akan mengoptimalkan semua potensi terbaik dari dalam diri kita. Cintai kehidupan kita, dan cintai diri kita dengan ikhlas, untuk menjalani apapun yang harus dijalani. Memperhatikan diri sendiri menjadikan kita mampu menemukan siapa kita sebenarnya. Ketika sudah mengetahui siapa kita, maka sangatlah mudah untuk menumbuhkan dan mengelola diri kita untuk mewujudkan yang kita inginkan (Djajendra, 2015 : 1). Untuk belajar memperhatikan diri sendiri, hendaknya melakukan hal-hal berikut :

1) Perhatikan diri sendiri.

2) Perhatikan penampilan.

3) Olahraga teratur.

4) Tidurlah yang cukup.

d. Menentukan tujuan dan mengambil resiko

Proses identifikasi, analisis, penilaian, pengendalian, dan upaya menghindari, meminimalisir, atau bahkan menghapus risiko yang tidak dapat diterima merupakan tujuan yang diharapkan semua orang dalam mengambil sikap. Supaya keinginan tersebut dapat kita lakukan, kita dapat memperhatikan hal-hal dibawah ini :

1) Tentukan tujuan yang kecil dan dapat dicapai. Banyak orang yang menentukan tujuan tidak realistis atau tidak dapat dicapai, lalu merasa kewalahan atau tidak pernah memulainya sama sekali

2) Sambutlah apa yang belum diketahui. Orang-orang yang kurang percaya diri cemas mereka tidak akan pernah berhasil dalam situasi yang tidak dapat diramalkan. Sekarang kita harus berhenti meragukan diri sendiri dan cobalah sesuatu yang benar-benar baru, tidak kita ketahui, dan berbeda.

3) Atasi apa yang kita anggap sebagai kelemahan. Mungkin ada beberapa hal dari diri kita yang tidak disukai namun tidak bisa diubah. Akan tetapi, kemungkinan ada banyak hal yang selama ini dianggap kelemahan sebenarnya dapat diatasi dengan sedikit usaha dan kerja keras.

4) Bantulah orang lain. Saat kita menyadari bahwa baik kepada orang-orang di sekitar dan membuat perubahan positif dalam hidup orang lain, kita 
akan mengetahui bahwa kita adalah kekuatan positif di dunia ini, dan ini akan meningkatkan rasa percaya diri.

\section{Menumbuhkan motivasi sosial}

Motivasi sosial memiliki peranan yang penting dalam pembelajaran, untuk memaksimalkan tercapainya tujuan pembelajaran maka seorang pendidik harus mampu menumbuhkan motivasi sosial peserta didiknya agar selalu dalam aktif dalam proses belajar. Salah satu cara menumbuhkan motivasi sosial pada mahasiswa adalah seorang dosen harus mampu menghadirkan suasana belajar yang menarik dan membangkitkan semangat belajar mahasiswa.

Sebelum kita mengkaji tentang cara menumbuhkan motivasi sosial peserta didik, terlebih dahulu kita harus memahami apa penyebab kurangnya motivasi sosial pada pesertak didik. berikut beberapa faktor yang biasanya menyebabkan kurangnya motivasi sosial pada mahasiswa :

a. Pembelajaran yang monoton.

b. Sarana pendidikan yang tidak memadai.

c. Rendahnya ikatan sosial antara dosen dengan mahasiswa.

Hal tersebut merupakan beberapa faktor yang menyebabkan rendahnya motivasi sosial mahasiswa, jika kondisi tersebut dibiarkan dan tak mendapat perhatian serius dari dosen, maka akan memberi dampak negatif kepada mahasiswa. Selanjutnya adalah bagaimana cara agar motivasi sosial dapat tumbuh, hal tersebut dijelaskan sebagai berikut :

a. Jadikan mahasiswa peserta aktif

b. Buatlah tugas yang menantang namun realistis dan sesuai

c. Ciptakan suasana kelas yang kondusif

d. Berikan tugas secara proporsional

e. Libatkan dosen untuk membantu mahasiswa mencapai hasil

f. Berikan petunjuk pada para mahasiswa agar sukses dalam belajar

g. Hindari kompetisi antar pribadi

h. Berikan masukan

i. Hargai kesuksesan dan keteladanan 
j. Antusias dalam mengajar

k. Tentukan standar yang tinggi namun realisitis bagi seluruh mahasiswa

1. Pemberian penghargaan untuk memotivasi

m. Ciptakan aktifitas yang melibatkan seluruh mahasiswa dalam kelas

n. Hindari penggunaan ancaman

o. Hindarilah komentar buruk

p. Kenali minat mahasiswa

q. Peduli dengan mahasiswa

3. Faktor yang mempengaruhi keaktifan

Keaktifan dalam proses pembelajaran dapat dirangsang dan mengembangkan bakat yang dimilikinya, mahasiswa juga dapat berlatih untuk berfikir kritis dan serta dapat memecahkan permasalahan-permasalahan dalam kehidupan sehari-hari. Terdapat faktor-faktor yang dapat mempengaruhi timbulnya keaktifan dalam proses pembelajaran. Menurut Gagne dan Briggs (dalam Yamin, 2017 : 84), faktor-faktor tersebut diantaranya :

a. Memberikan dorongan atau menarik perhatian, sehingga mereka dapat berperan aktif dalam kegiatan pembelajaran.

b. Menjelaskan tujuan intruksional.

c. Mengingatkan kompetensi belajar.

d. Memberikan stimulus (masalah, topik dan konsep yang akan dipelajari).

e. Memunculkan aktivitas, partisipasi dalam kegiatan pembelajaran.

f. Memberi umpan balik (feed back)

g. Melakukan serangkaian test kepada mahasiswa berupa quiz, sehingga kemampuan merekaa selalu terpantau dan terukur.

h. Menyimpulkan setiap materi yang disampaikan di akhir perkuliahan.

\section{E. KESIMPULAN}

Berdasarkan analisis yang penulis lakukan tentang pentingnya meningkatkan kepercayaan diri yang kaitannya dengan motivasi sosial mahasiswa dalam mengikuti proses KBM pada program studi kesehatan masyarakat STIKes Cirebon tingkat I semester I tahun akademik 2019/2020. 
Mahasiswa yang memiliki tingkat kepercayaan diri yang tinggi akan cenderung memiliki motivasi sosial yang tinggi pula, dengan demikian mereka dengan otomatis akan turut serta aktif dalam proses KBM. Hal tersebut terjadi karena dengan pengetahuan tentang materi yang ia miliki, dapat meningkatkan kepercayaan diri, dan efeknya akan mendorong mahasiswa tersebut untuk berperan aktif selama proses KBM berlangsung.

\section{DAFTAR PUSTAKA}

Agung Sunarto dan Agung Hartono. (2016). Perkembangan Peserta Didik. Jakarta: PT. Asdi Mahasatya.

Anggraini, A. P. (2018). Memahami Pentingnya Rasa Percaya Diri dalam Kehidupan. Retrieved October 22, 2018, from Kompas.com website: https://lifestyle.kompas.com/read/2018/09/05/111100720/memahamipentingnya-rasa-percaya-diri-dalam-kehidupan-?page=all .

Badan Pengembangan Bahasa dan Perbukuan, K. P. dan K. R. I. (2016). KBBI Daring. Retrieved October 23, 2019, from 23/10/2019 website: https://kbbi.kemdikbud.go.id/.

Basyiruddin Usman. (2012). Guru Profesional. Jakarta: Ciputat Press.

Burhan Bungin. (2008). Metode Penelitian Kuantitatif. Jakarta: Kencana.

Dimyati, \& Mudjiono. (2009). Belajar dan Pembelajaran. Jakarta: Rineka Cipta.

Djajendra. (2015). Memperhatikan Diri Sendiri. Retrieved October 23, 2019, from 11/4/2015 website: https://djajendra-motivator.com/?p=9323.

Djamarah dan Syaiful Bakhri. (2018). Psikologi Belajar. Jakarta: Rineka Cipta.

Eveline Siregar dan Hartini Nara. (2010). Teori Belajar dan Pembelajaran. Bogor: Ghalia Indonesia.

Hamzah B. Uno. (2011). Teori Motivasi dan Pengukurannya Analisis di Bidang Pendidikan. Bandung: Gaung Persada.

M.D., N. B. (2012). Building Confidence and Self-Esteem. Retrieved October 23, 2019, from 30/5/2012 website: https://www.psychologytoday.com/intl/blog/hide-andseek/201205/building-confidence-and-self-esteem

Mind Tools. (2019). Building Self-Confidence. Retrieved October 23, 2019, from 22/10/2019 website: https://www.mindtools.com/selfconf.html. 
Muhammad Ali. (2017). Guru dalam Proses Belajar Mengajar. Bandung: Sinar Baru Algesindo.

Nasution. (2014). Manajemen Data Terpadu. Bogor: Ghalia Indonesia.

Noeng Muhadjir. (2017). Metodologi Keilmuan: Paradigma Kualitatif, Kuantitatif, dan Mixed. Yogyakarta: Rake Sarasin.

Nugroho, P. (2017). Pengembangan Model Pembelajaran IPS Terpadu Berbasis Lingkungan. Jurnal Ilmu Pendidikan, 22(2), 125-133. https://doi.org/10.17977/jip.v22i2.8732.

Sardiman, A. . (2010). Interaksi dan Motivasi Belajar Mengajar. Jakarta: PT. Raja Grafindo Persada.

Yamin, M. (2017). Profesionalisasi Guru \& Implementasi KTSP. Jakarta: Gaung Persada. 